\title{
Pandémie, iniquités, santé publique, information, interventions : l'échec canadien?
}

\section{Pandemics, inequities, public health, information, response: Canada's failure?}

\author{
François Béland ${ }^{1,2}$ \\ Published online: 9 April 2021 \\ (C) The Canadian Public Health Association 2021
}

Une pandémie transforme radicalement le paysage sociosanitaire. Les réseaux de santé cherchent à s'adapter à la réalité nouvelle, des soins sont détournés de leur destination habituelle, des plans d'urgence sont déployés pour faire front aux conséquences de la pandémie, la prestation des services de santé s'ajuste pour offrir des soins fonctionnellement équivalents (Hick \& Hanfling 2020). Si la situation dégénère, les plans d'urgence cèdent alors la place à une stratégie de crise. La communication rapide d'informations accessibles, mesurables, valides, pertinentes, interprétables et pragmatiques (Blair et coll. 2021) joue un rôle fondamental dans la planification d'interventions toujours urgentes en temps de pandémie (Fineberg 2020). L'identification et le suivi des groupes vulnérables (Frohlich \& Potvin 2008) et des personnes à risque sont des soucis communs (Blair et coll. 2021). Enfin, en situation de pandémie, «personne n'est protégée tant que tout le monde n'est pas protégé » (ASPC 2020 : 2). En conséquence, la collecte d'information et l'ouverture de lignes rapides de communication sont des nécessités (Fineberg 2020).

En temps de pandémies, une des fonctions d'un système d'information est de générer celles qui permettront de voir venir les pandémies, de les contrôler et de les éviter (Challener et coll. 2020). L'approche est populationnelle et vise la protection des populations. L'appareil de la santé

François Béland

francois.beland@umontreal.ca

1 Département de gestion, d'évaluation et de politique de santé, École de santé publique, Université de Montréal, Montréal, Québec, Canada

2 Institut Lady Davis, Hôpital juif de Montréal, Université McGill, Montréal, Québec, Canada publique doit être prêt en tout temps à mobiliser les ressources pour identifier, dès les tout premiers signaux de pandémie, les premiers cas d'infection, tracer les contacts, isoler les éclosions et tester, tester, tester (Matukas et coll. 2020). La performance de la santé publique au Canada pâlit devant les succès d'un petit pays comme l'Uruguay lors de la première vague de la COVID-19 (Taylor 2020). Prédire, contrôler et éviter les pandémies, sinon endiguer leurs premières manifestations, valent mieux à cet égard que toute autre panoplie d'interventions pour protéger les populations vulnérables et les groupes à risque.

Le Rapport de l'administratrice en chef de l'Agence de la santé publique du Canada sur la première vague de la pandémie de la COVID-19 (ASPC 2020 : 35-36) place au centre de ses préoccupations «l'accès différentiel aux ressources matérielles, aux privilèges et au pouvoir, et les inégalités en matière de santé qui en ont découlé...» (ASPC 2020 : 19). L'entrecroisement des inégalités matérielles, des rangs sociaux et des hiérarchies de pouvoir génère des populations vulnérables qui cumulent les inégalités de santé. Il s'agit d'utiliser une stratégie raisonnée d'identification des populations vulnérables et des conséquences de la pandémie sur leur santé (Culyer 2007). Comme le suggère Blair et coll. (2021), l'objectif est de fixer en situation d'urgence ou de crise les efforts de la santé publique sur les actions spécifiques à entreprendre auprès de ces populations. Au Canada, les préoccupations pour les groupes vulnérables ne sont survenues qu'une fois que les sommets de prévalence de la COVID-19 ne pouvaient passer inaperçus.

Les groupes à risque varient avec les épidémies. Les personnes âgées, celles du quatrième âge en particulier, ont été victimes de la COVID-19. Par contre, les jeunes ont été visés par l'épidémie d'A(H1N1) (INSPQ 2011). Ces populations vivent ou fréquentent des milieux amplificateurs de risque : les centres 
d'hébergement de soins de longue durée et les écoles. La préparation à long terme aux pandémies dans les milieux est une des étapes d'une politique de santé publique préoccupée par les iniquités. La première vague de COVID-19 a montré la grande négligence dont ont fait preuve les administrations publiques vis-à-vis des mesures de santé publique dans les milieux et les établissements. Ces administrations avaient pourtant produit une vaste série de documents et de lignes directrices sur les infections nosocomiales au sortir de l'épidémie de SARSCoV-1. D'ailleurs, les recommandations de la Société royale du Canada (Estabrooks et coll. 2020) répètent ce qui était parfaitement connu. Par contre, au cours de ces années, les mesures concrètes ne s'implantent qu'en milieu hospitalier. Tout le reste a été négligé. Il ne suffit pas de produire de l'information pour que suivent les actions. Il n'y a que la santé publique pour assurer la pérennité des mesures de contrôle et prévention des infections dans les milieux et les établissements. Elle doit être partie liée à la transformation des systèmes de santé (Millar et coll. 2013). La pandémie de COVID-19 a mis en évidence les défaillances dans les réseaux de la santé de la collecte assidue d'information sur l'incidence et la prévalence des infections chez les groupes et les milieux à risque. Un système d'information en continu sur l'organisation des mesures de prévention et de contrôle dans les milieux doit préexister et fonctionner avant les pandémies.

L'article de Blair et coll. (2021) est un signal d'alerte. Que fautil pour que les administrations publiques soient plus qu'agacées par des sonneries stridentes? Au cours de l'année qui vient de s'écouler, on a souvent entendu l'expression « construire l'avion en plein vol ». Il a bien fallu s'y astreindre et faire ou refaire en partie la santé publique autour de la réponse à la COVID-19. Les administrations publiques se sont condamnées elles-mêmes à cette peine. Si les connaissances sur le virus SARS-CoV-2 étaient bien minces au premier jour de la pandémie, les mesures traditionnelles de lutte contre les pandémies ne sont pas des puits de mystère. Être prêt était à notre portée.

François Béland, Ph. D.

Professeur titulaire, École de santé publique, Université de Montréal

\section{Editorial}

A pandemic radically changes the social and healthcare landscape. Health networks work to adapt to a new reality, healthcare takes different avenues, contingency plans are rolled out to deal with the consequences of the pandemic, and health service delivery adjusts to offer functionally equivalent care (Hick \& Hanfling 2020). If the situation escalates, contingency plans give way to crisis strategies. Rapid communication of information that is accessible, measurable, valid, relevant, interpretable, and practical (Blair et coll. 2021) is fundamental when planning the urgent response that is always required during a pandemic (Fineberg 2020). Identifying and tracking vulnerable groups (Frohlich \& Potvin 2008) and atrisk individuals are common concerns (Blair et coll. 2021). Finally, in a pandemic situation, "no one is safe until everyone is safe" (ASPC 2020, p. 2). Therefore, gathering information and rapidly opening lines of communication becomes essential (Fineberg 2020).

During outbreaks, one of the roles of an information system is to generate mechanisms that can predict, track, and prevent a pandemic (Challener et coll. 2020). It is a population-based approach that aims to protect populations. The public health system must always be ready, from the very first signs of a pandemic, to mobilize resources in order to find the first infectious cases, trace contacts, isolate outbreaks, and test, test, test (Matukas et coll. 2020). Canada's public health performance pales in comparison to the success of a small country like Uruguay during its first COVID-19 wave (Taylor 2020). Predicting, tracking, and preventing pandemics, or at the very least, containing the first cases, is a more reliable way of protecting vulnerable populations and at-risk groups than a whole other array of responses.

One of the foremost concerns mentioned in the Public Health Agency of Canada's Chief Public Health Officer's report on the first wave of the COVID-19 pandemic (ASPC 2020, pp. 35-36) was the "...differential access to material resources, privilege and power, and the resulting health inequities ..." (ASPC 2020, p. 19). The intersection of material inequality, social status, and power structures creates vulnerable populations that are differentially impacted by health inequities. A reasoned strategy must be used to identify vulnerable populations and the impacts a pandemic has on their health (Culyer 2007). As Blair et al. suggest (2021), the goal in an emergency or crisis is to focus public health efforts on specific actions that can be taken for these populations. In Canada, vulnerable groups only became a cause for concern once the COVID-19 numbers could no longer be ignored.

At-risk groups vary depending on the epidemic. Older people, especially the very old, have been victims of COVID-19. On the other hand, the influenza A (H1N1) pandemic affected young people (INSPQ 2011). These populations live in or spend time in environments that amplify risk: long-term care homes and schools. Long-term pandemic preparation in these settings is one of the steps that a public health policy concerned with inequities must take. The first wave of COVID19 revealed governments' massive negligence of public health measures in these settings and institutions, even though they had produced a wide range of documents and guidelines on nosocomial infections in the aftermath of the SARS-CoV-1 pandemic. In fact, the recommendations by the Royal Society of Canada (Estabrooks et coll. 2020) repeat what was clearly already known. However, over the years, these concrete measures were only implemented in hospital settings. Everything else was overlooked. It is not enough to produce information 
and then expect action to follow. Only the public health system can ensure the continuity of infection control and prevention measures in settings and institutions, and it must be a central player in the transformation of the health system (Millar et coll. 2013). The COVID-19 pandemic highlighted the failure of health networks to comprehensibly gather information on the incidence and prevalence of infections in at-risk groups and settings. A continuous information system for organizing prevention and control measures in institutions must be present and operational before a pandemic occurs.

Blair et al.'s (2021) article is a wake-up call. What will it take for governments to show more than a passing interest in the warning signs? Over the past year, the expression "building the plane while you fly" has often been heard. Public administrations were tied up by the consequences of the pandemic and were compelled to create or partially re-create public healthcare based on our response to COVID-19. Governments have only themselves to blame. Even if knowledge about the SARS-CoV-2 virus was lacking in the first days of the pandemic, conventional methods of fighting pandemics are not mysterious black holes. Preparedness was within our reach.

François Béland, $\mathrm{PhD}$

Professor, School of Public Health, Université de Montréal

\section{Références bibliographiques/References}

ASPC - Agence de la santé publique du Canada et Réseau pancanadien de santé publique. (2020). Du risque à la résilience : une approche axée sur l'équité concernant la COVID-19. Gouvernement du Canada. https://www.canada.ca/fr/sante-publique/organisation/publications/ rapports-etat-sante-publique-canada-administrateur-chef-santepublique/du-risque-resilience-approche-equite-covid-19.html.

Blair, A., Warsame, K., Naik, H., Byrne, W., Parni, A., \& Siddiqi, A. (2021). Identifying gaps in COVID-19 health equity data reporting in Canada using a scorecard approach. CMAJ. https://doi.org/10. 1101/2020.09.23.20200147. medRxiv preprint.
Challener, D. W., Dowdy, S. C., \& O'Horo, J. C. (2020). Analytics and prediction modeling during the COVID-19 pandemic. Mayo Clin Proc, 95(9S), S8-S10. https://doi.org/10.1016/j.mayocp.2020.05. 040.

Culyer, A. J. (2007). Equity of What in Healthcare? Why the traditional answers don't help policy - and what to do in the future. Healthcare Papers, 8(Special number), 12-26. https://doi.org/10.12927/hcpap. 2007.19216.

Estabrooks, C. A., Straus, S., Flood, C. M., Keefe, J., Armstrong, P., Donner, G., Boscart, V., Ducharme, F., Silvius, J., \& Wolfson, M. (2020). Rétablir la confiance : la COVID-19 et l'avenir des soins de longue durée. Société royale du Canada https://rsc-src.ca/sites/ default/files/LTC\%20PB_FR.pdf.

Fineberg, H. V. (2020). Rapid expert consultation on data element and systems design for modeling and decision making for the COVID-19 pandemic (March 21, 2020), National Academies of Sciences, Engineering, and Medicine (Vol. 10, p. 17226/25784). Washington, DC: The National Academies Press.

Frohlich, K. L., \& Potvin, L. (2008). Transcending the known in public health practice: the inequality paradox: The population approach and vulnerable populations. Am J Public Health, 98(2), 216-221. https://doi.org/10.2105/AJPH.2007.114777.

Hick, J., \& Hanfling, D. (2020). Rapid expert consultation on crisis standards of care for the COVID-19 pandemic (March 21,2020), National Academies of Sciences, Engineering, and Medicine. Washington, DC: The National Academies Press. https://doi.org/ $10.17226 / 25784$.

INSPQ - Institut national de la santé publique du Québec. (2011). Bilan épidémiologique de la pandémie d'influenza (a(H1N1)). Gouvernement du Québec: Québec https://www.inspq.qc.ca/pdf/ publications/1212_BilanAH1N12009.pdf.

Matukas, L. M., Dhalla, I. A., \& Laupacis, A. (2020). Trouver, tester, « tracer » et isoler énergiquement pour battre la COVID-19. CMAJ, 192(50), E1836-E1837. https://doi.org/10.1503/cmaj.202120-f.

Millar, J., Bruce, T., Cheng, S. M., Masse, R., \& McKeown, D. (2013). Is public health ready to participate in the transformation of the healthcare system? Healthcare Papers, 13(33), 10-20 https:// www.longwoods.com/content/23689/healthcarepapers/is-publichealth-ready-to-participate-in-the-transformation-of-the-healthcaresystem.

Taylor, L. (2020). Uruguay is winning against COVID-19. This is how. British Medical Journal, 370, m3575. https://doi.org/10.1136/bmj. m3575.

Publisher's note Springer Nature remains neutral with regard to jurisdictional claims in published maps and institutional affiliations. 